\title{
Evaluation of Growth Parameters and Biochemical Markers of Corn Plants Under Saline Stress
}

\author{
Ana Cláudia Graças Alves Viana \\ Universidade Paranaense - Programa de Pós-Graduação em Biotecnologia Aplicada à \\ Agricultura \\ Praça Mascarenhas de Moraes, 4282 - Centro, Umuarama-Paraná, Brazil \\ E-mail: ana.claudia.graca@gmail.com
}

\section{Franciele da Silva Quemel}

Universidade Paranaense - Programa de Pós-Graduação em Biotecnologia Aplicada à Agricultura

Praça Mascarenhas de Moraes, 4282 - Centro, Umuarama-Paraná, Brazil

E-mail: franciele.quemel@edu.unipar.br

Janyeli Dorini Silva de Freitas

Universidade Paranaense - Programa de Pós-Graduação em Biotecnologia Aplicada à Agricultura

Praça Mascarenhas de Moraes, 4282 - Centro, Umuarama-Paraná, Brazil

E-mail: janyeli.s.freitas@edu.unipar.br

João Paulo Francisco

Universidade Estadual de Maringá

Estrada Paca - Jardim São Cristóvão, Umuarama - PR, Brazil

E-mail: jpfrancisco2@uem.br

Antonio Nolla

Universidade Estadual de Maringá

Estrada Paca - Jardim São Cristóvão, Umuarama - PR, Brazil 
E-mail: nolla73@hotmail.com

\begin{abstract}
Ana Daniela Lopes (Corresponding author)
Universidade Paranaense - Programa de Pós-Graduação em Biotecnologia Aplicada à Agricultura
\end{abstract}

Praça Mascarenhas de Moraes, 4282 - Centro, Umuarama-Paraná, Brazil

Tel: 44998039911 E-mail: anadanielalopes@prof.unipar.br

Received: August 13, 2019

doi:10.5296/jas.v7i4.15262
Accepted: Sep. 5, 2019

Published: Sep. 11, 2019

URL: https://doi.org/10.5296/jas.v7i4.15262

\begin{abstract}
This study aimed to investigate the effect of salinity on growth parameters and oxidative stress markers in leaves and roots of two sweet corn genotypes: BR 427III, obtained from Embrapa Milho e Sorgo, and Tropical Plus®, a commercial hybrid. The genotypes were kept in 15-L pots with typical dystrophic red latosol soil, and irrigated with $\mathrm{NaCl}$ solution $(0,25,50,100$, 150 and $300 \mathrm{mM}$ ). At 105 days after planting, the samples were collected, immediately frozen in liquid nitrogen, and stored at $-80^{\circ} \mathrm{C}$ for posterior analyses. After this period, it was verified that, while $\mathrm{NaCl}$ concentration increased, there was a decrease in leaf and root fresh and dry masses as well as in shot and root lengths of both evaluated genotypes. A decrease in the stem diameter of BR427III genotype plants and in the chlorophyll index of both genotypes was observed. Sodium accumulation in the root and leaves increased according to the stress severity; however, potassium content reduced in both roots and leaves. Proline content increased significantly in the leaves of both evaluated genotypes when exposed to higher concentrations of $\mathrm{NaCl}$. On the other hand, malondialdehyde content decreased in leaves and root of Tropical Plus genotype, where an increase in electrolyte overflow from membrane damage caused by stress severity was observed.
\end{abstract}

Keywords: Zea mays L. saccharata, Salinity, Sweet corn

\title{
1. Introduction
}

Soil salinity is a serious threat to productivity and has limited agricultural production worldwide (Gheyi et al., 2016). During the vegetative period, corn plants present greater sensitivity to salinity, and show greater tolerance during flowering (Bezerra et al., 2010), although they may be influenced by genotype characteristics regarding sensitivity.

The effect of soil salinity can trigger damages to the cell membrane, causing electrolyte overflow, or inducing malondialdehyde (MDA) accumulation. MDA results from lipid peroxidation and its increase indicates oxidative stress (Garcia et al., 2007). In order to reduce 
these effects, it is essential to investigate the physiological metabolism of plants submitted to salinity to select more tolerant materials to be utilized in plant breeding (Ahmed et al., 2015). Salinity-tolerant plants adopt strategies such as the osmotic adjustment mechanism (Willadino et al., 2011), $\mathrm{K}^{+}$and $\mathrm{Na}^{+}$accumulation in the cytoplasm to favor osmotic adjustment, and also the accumulation of organic solutes such as some amino acids like proline, glycine and betaine (Munns \& Gilliham, 2015).

Proline has an important protective function in the plant that is responsible for the osmotic adjustment, stabilizes proteins and antioxidant enzymes, and contributes to eliminate species that are reactive to oxygen by increasing the gene expression of enzymes with antioxidant function which signals stress (Shtereva et al., 2015). Therefore, this study aimed to study the effect of $\mathrm{NaCl}$ salinity on growth parameters and oxidative stress markers in leaves and roots of two sweet corn genotypes as well as to estimate their tolerance to saline stress.

\section{Material and Methods}

The experiment was carried out at the Campus III of Paranaense University - UNIPAR, in the city of Umuarama, PR, Brazil, under greenhouse conditions from June to September, 2017. During this period, the recorded temperature and average relative humidity were $24.4{ }^{\circ} \mathrm{C}$ and $77 \%$, respectively.

The vegetal matter consisted of two sweet corn (Zea mays saccharata) genotypes: BR 427III, obtained from Embrapa Milho e Sorgo, and Tropical Plus®, a commercial hybrid. Neither of the evaluated materials has been reported in the literature regarding their tolerance to these abiotic stresses.

Typical dystrophic red latosol soil, obtained at the depth of $20 \mathrm{~cm}$ in the fertile layer of the soil profile from the city of Umuarama, was used to fill up 15-L plastic pots. The seeds from both sweet corn genotypes were placed in the pots which were irrigated daily with water until seedling emergence. Next, soil salinization was started with the application of solutions at $\mathrm{NaCl}$ concentrations of $0,25,50,100,150$ and $300 \mathrm{mM}$. At 105 days after planting, the samples were collected, immediately frozen in liquid nitrogen, and stored at $-80^{\circ} \mathrm{C}$ for posterior analyses.

Plant height and root length were measured with a 2-m measuring tape. The length of root system base up to the last visible leaf was used to estimate the aerial part length. The aerial part fresh mass was obtained by weighing it in a semi-analytic scale.

The leaves were kept in an air circulation stove at $50{ }^{\circ} \mathrm{C}$ until reaching constant mass in order to obtain the dry mass. The stem diameter was determined by measuring the stem medial part with $300 \mathrm{~mm} / 12$ digital calipers. The chlorophyll index was determined by a portable SPDA-502 device (Soil and Plant Analysis Development - Minolta Co).

Sodium $\left(\mathrm{Na}^{+}\right)$and potassium $\left(\mathrm{K}^{+}\right)$contents were determined from the root and leaf dry mass according to the methodology described by Carmo et al. (2000), with adaptations. The previously dried samples were grounded and sieved in $1.18 \mathrm{~mm}$ mesh. Approximately $0.5 \mathrm{~g}$ of leaves and roots were submitted to previous digestion with nitric acid in digesting tubes for 12 $\mathrm{h}$, and then heated in a block digester at $120^{\circ} \mathrm{C}$ for three hours. 
After partial digestion, perchloric acid $\left(\mathrm{HClO}_{4}\right)$ was added to the samples which were kept in a block digester at $200{ }^{\circ} \mathrm{C}$ for 3 hours. Then, when cooled, the volume in the tube was completed with ultrapure water up to $25 \mathrm{~mL}$, and readings were done in a flame photometer. Proline concentration was determined through the methodology by Bates et al. (1973), as described by Guzel \& Terzi (2013). The lipid peroxidation level was determined by estimating malondialdehyde (MDA) content according to Cakmak \& Hosrt (1991). The absorbance reading was done at 532 and $660 \mathrm{~nm}$ (unspecified absorbance to be deduced) in a spectrophotometer.

Lipid peroxidation was estimated as the total content of reactive substances to thiobarbituric acid (TBA) and expressed as MDA equivalents. MDA molar extinction expression (155 mM $\mathrm{cm}^{-1}$ ) was utilized for calculations and the results were expressed in nmol MDA g${ }^{-1} \mathrm{MF}$.

The percentage of membrane damage (\%MD), estimated from the electrolyte overflow, was determined through five $3-\mathrm{cm}$ diameter foliar disks immersed in distilled water. The disks were kept in assay tubes under agitation at $28^{\circ} \mathrm{C}$ for $24 \mathrm{~h}$. Next, the reading of the solution electric conductivity (L1) was done. Later, the tubes were incubated in a water bath at $100{ }^{\circ} \mathrm{C}$ for $1 \mathrm{~h}$, and a new reading of the solution electric conductivity (L2) was done after cooling at ambient temperature. The \%MD was estimated by the equation EL $(\%)=(\mathrm{L} 1 / \mathrm{L} 2) * 100$ (Silveira et al., 2001).

The experiment was totally randomized and had 2x6 factorial design with two sweet corn genotypes (Tropical Plus and BR 427III) and six saline concentrations $(\mathrm{NaCl})(0,25,50,100$, 150 and $300 \mathrm{mM}$ ). Each treatment consisted of six replications, and the evaluations were done 99 days after the beginning of soil salinization.

Except for the growth parameters, the indirect measurement of chlorophyll contents and electrolyte overflow, whose analyses were done in hexaplicate, all the other variables were analyzed in triplicate. The obtained data were submitted to analysis of variance at $5 \%$ and, when significant, regression was applied for the concentrations, and Tukey's at 5\% of probability was applied for the genotypes. When the interaction was significant, concentration deployment was estimated for each genotype by regression, and genotype deployment was estimated for each concentration by Tukey's at 5\%. The analyses were done using Sisvar software (Ferreira, 2011).

\section{Results and Discussion}

The aerial part and root lengths were inhibited by salinity. A height reduction of approximately 64\% was observed in Tropical Plus genotype, and of 78\% in BR 427III during the most severe stress level $(300 \mathrm{mM})$. The concentration deployment of each genotype by regression was significant for both genotypes (Figure 1). The linear regression model was the one that best adjusted to the data for Tropical Plus, and the quadratic one for BR 427III. 

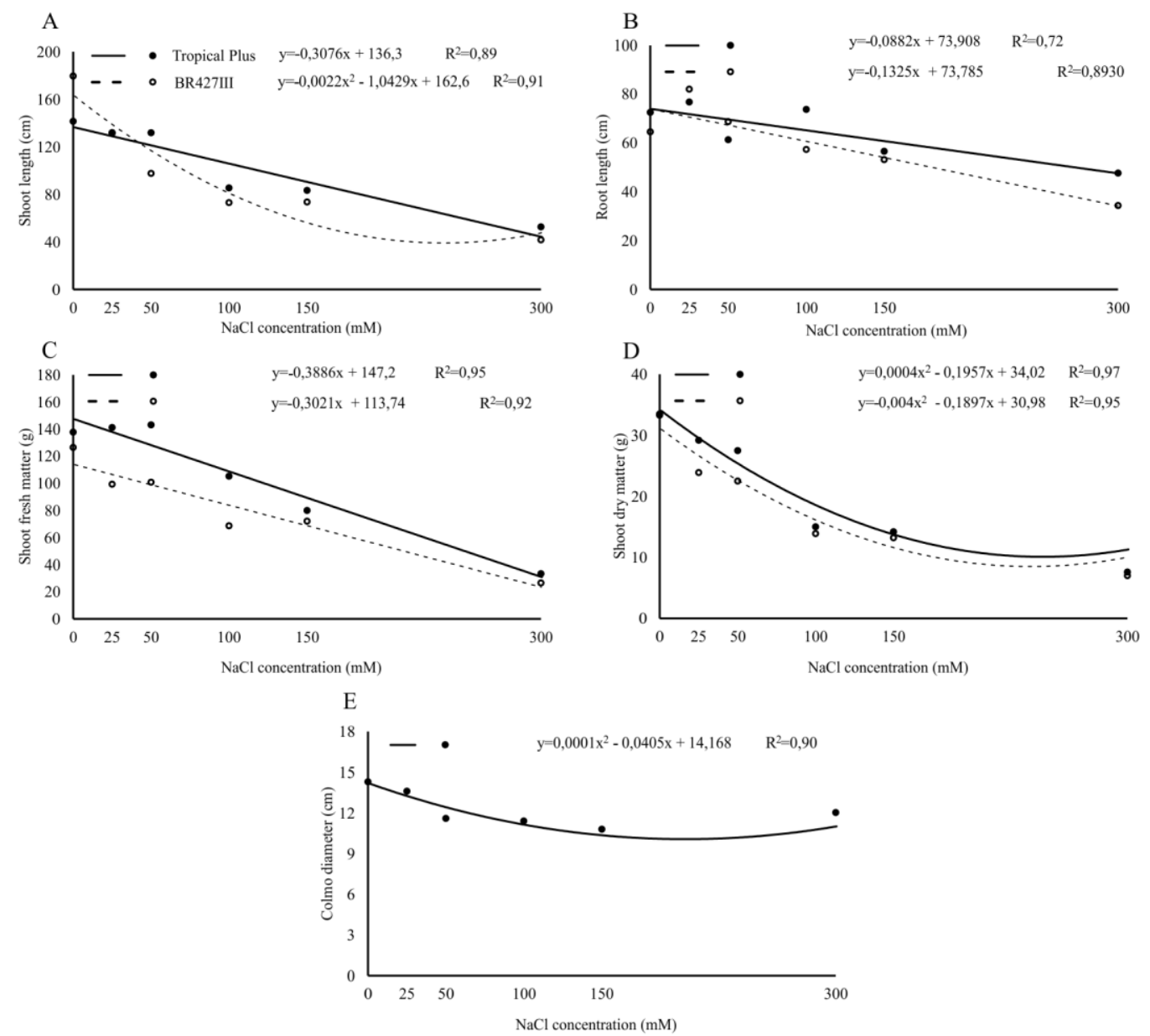

Figure 1. Aerial part length (A), root length(B), fresh mass (C) and dry mass (D) of the aerial part, and stem diameter (E) of sweet corn genotypes, Tropical Plus and BR 427III, submitted to different saline concentrations $(\mathrm{NaCl})$ in the soil

The decrease in the root length (Figure 1B) was smaller and presented values that were lower than $50 \%$ of the growth inhibition. For the root system, the linear regression model was adopted for both genotypes, making evident that the increase in $\mathrm{NaCl}$ concentration is reflected in the root length reduction.

Root growth is a parameter that is influenced by salinity because salt excess in the soil, or in the irrigation water, reduces the mass and induces osmotic adjustment mechanisms in corn plants (Farooq et al., 2015 and Hajlaoui et al., 2010). Saadat \& Homaee (2015) reported a reduction of up to $50 \%$ in the root growth of sorghum (Sorghum bicolor L. Moench) submitted to saline stress. According to the authors, in order to decrease the metabolic cost, a plant regulates its ion transport and distribution to several organs and within the cells, reducing the synthesis of organic solutes for osmoregulation and/ or macromolecular protection. Thus, among other factors, a smaller growth reduction can be associated with a smaller energy cost for osmoregulation. 


\section{Macrothink}

There was reduction in the aerial part fresh mass (Figure 1C) of 75 and $80 \%$ in Tropical Plus and BR 427III, respectively, when comparing the control to the treatment with $300 \mathrm{mM}$ of $\mathrm{NaCl}$. The linear regression model adjusted better to the data of Tropical Plus as well as BR 427III.

Similarly, the aerial part dry mass (Figure 1D) was also reduced. There was no significant difference between the evaluated genotypes. This behavior has been considered typical in plant irrigated with saline water (Santos et al., 2012) because water absorption is prevented by the increase in the soil osmotic potential, reducing foliar turgescence which affects length as well as the dry mass of sensitive plants.

Both genotypes decreased biomass 4.5-fold, when comparing the control to the most severe stress level $(300 \mathrm{mM})$. Such a reduction may indicate a decrease in root growth and in $\mathrm{CO}_{2}$ assimilation (AbdElgawad et al., 2016), which would explain the reduction in the evaluated growth parameters.

The quadratic regression model adjusted better to the stem diameter data (Figure 1E). The stem diameter reduction in both genotypes may have been influenced by the plant growth since it is one of the most sensitive parameters to saline stress. According to Brito et al. (2013), this decrease may be related to closing of stomata and consequent reduction in carbohydrate formation during photosynthesis, resulting in a decrease of phytomass accumulation in the plant stem.

In Figure 2, the effect of saline concentrations $(\mathrm{NaCl})$ on $\mathrm{Na}^{+}$contents of roots and leaves (Figure $2 \mathrm{~A}$ and $2 \mathrm{~B}$ ) and on $\mathrm{K}^{+}$potassium contents of roots and leaves (Figure $2 \mathrm{C}$ and $2 \mathrm{D}$ ) in both evaluated genotypes are shown.
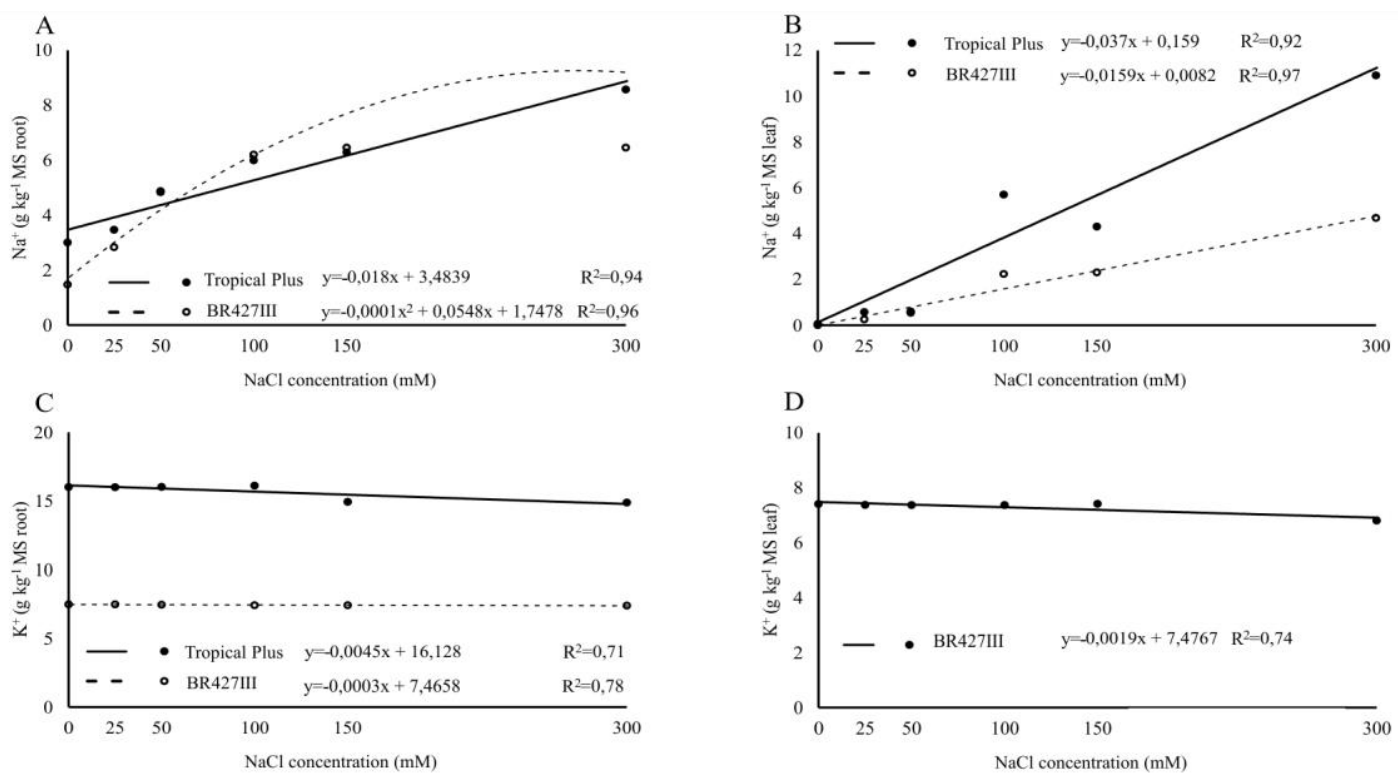

Figure 2. Sodium contents $\left(\mathrm{Na}^{+}\right)$in roots (A) and leaves (B); potassium contents $\left(\mathrm{K}^{+}\right)$in roots

(C) and leaves (D) of sweet corn genotypes, Tropical Plus and BR 427III, submitted to different saline concentrations $(\mathrm{NaCl})$ in the soil 
The high soil saline concentration increased $\mathrm{Na}^{+}$contents in the roots and leaves (Figure 2A). Sodium accumulation was greater in root cells, except for Tropical Plus (300 mM). Similar results had been described by AbdElgawad et al. (2016) who also verified greater $\mathrm{Na}^{+}$contents in the roots of corn seedlings submitted to saline stress at the concentrations of 0,75 and 150 $\mathrm{mM}$.

The increase of $\mathrm{Na}^{+}$content in the root was approximately $186 \%$ when comparing the control with the highest evaluated concentration $(300 \mathrm{mM})$. Although $\mathrm{Na}^{+}$content in the leaves was lower than in the roots, it was observed that the content became higher as concentration increased.

The linear regression model adjusted better to data for both genotypes. Tropical Plus and BR 427III significantly differed between themselves at the concentrations of 100, 150 and $300 \mathrm{mM}$ of $\mathrm{NaCl}$, and the former accumulated more $\mathrm{Na}^{+}$in the leaves (Figure 2A). The accumulation of $\mathrm{Na}^{+}$ions in the leaf tissues caused several physiological disorders that result in the stomatal closing and/or photosynthetic mechanism damage leading to low $\mathrm{CO}_{2}$ assimilation, according Acosta-Motos et al., (2017).

Moreover, other responses may be observed such as nutritional disorders and the emergence of oxygen-reactive species with consequent growth reduction, dry mass accumulation, and low productivity (AbdElgawad et al., 2016). A similar result was found by Garcia et al. (2007) when evaluating sodium accumulation in corn under saline stress, and they also detected higher values of this cation in the root, indicating, therefore, its accumulation in detriment of its translocation to the aerial part. Thus, in our study, besides presenting a greater concentration of sodium in the roots, it was observed that the plants also presented a lower growth rate, reflecting its deleterious effect on the vegetal tissue.

For $\mathrm{K}^{+}$content in the roots, the concentration deployment of each genotype was significant for both genotypes, making $\mathrm{K}^{+}$content reduction evident according to the increase in $\mathrm{NaCl}$ concentrations (Figure 2C and 2D). The genotypes BR 427III and Tropical Plus differed significantly between themselves for all tested concentrations, and the latter accumulated $\mathrm{K}^{+}$ approximately twice as much as the former.

It was observed that, in absolute values, $\mathrm{K}^{+}$contents were superior in roots when compared to the leaf content, similarly to the results found by AbdElgawad et al. (2016) when evaluating the behavior of corn seedlings under saline stress, and Hajibagheri et al. (1987) when assessing corn tolerance to salt.

A reduction in $\mathrm{K}^{+}$content was observed as salinity increase. The behavior of Tropical Plus makes evident that the increase in $\mathrm{NaCl}$ concentrations utilized for soil salinity did not affect negatively the absorption and translocation of $\mathrm{K}^{+}$to leaves, corroborating the results described for $\mathrm{K}^{+}$contents in roots.

Similar results were observed in the study by Cruz (2018) on sugarcane leaves under saline stress where there was not significant difference between potassium content and the evaluated saline concentrations. These results were relevant because potassium is an important element for plant growth and development, mainly as it helps keep the osmotic potential and due to its 
important role in the activation of more than 50 metabolic enzymes (Wakeel, 2013), suggesting that there is a strategy of both genotypes to keep a satisfactory level of $\mathrm{K}$ in the root in order to survive the stress condition evaluated in this study.

Figure 3 shows the effect of $\mathrm{NaCl}$ saline concentrations on the chlorophyll index (Figure $3 \mathrm{~A}$ ), proline (Figure 3B), malonialdehyde (MDA) test in roots (Figure 3C) and leaves (Figure 3D), and electrolyte overflow (Figure 3E) in both evaluated genotypes.
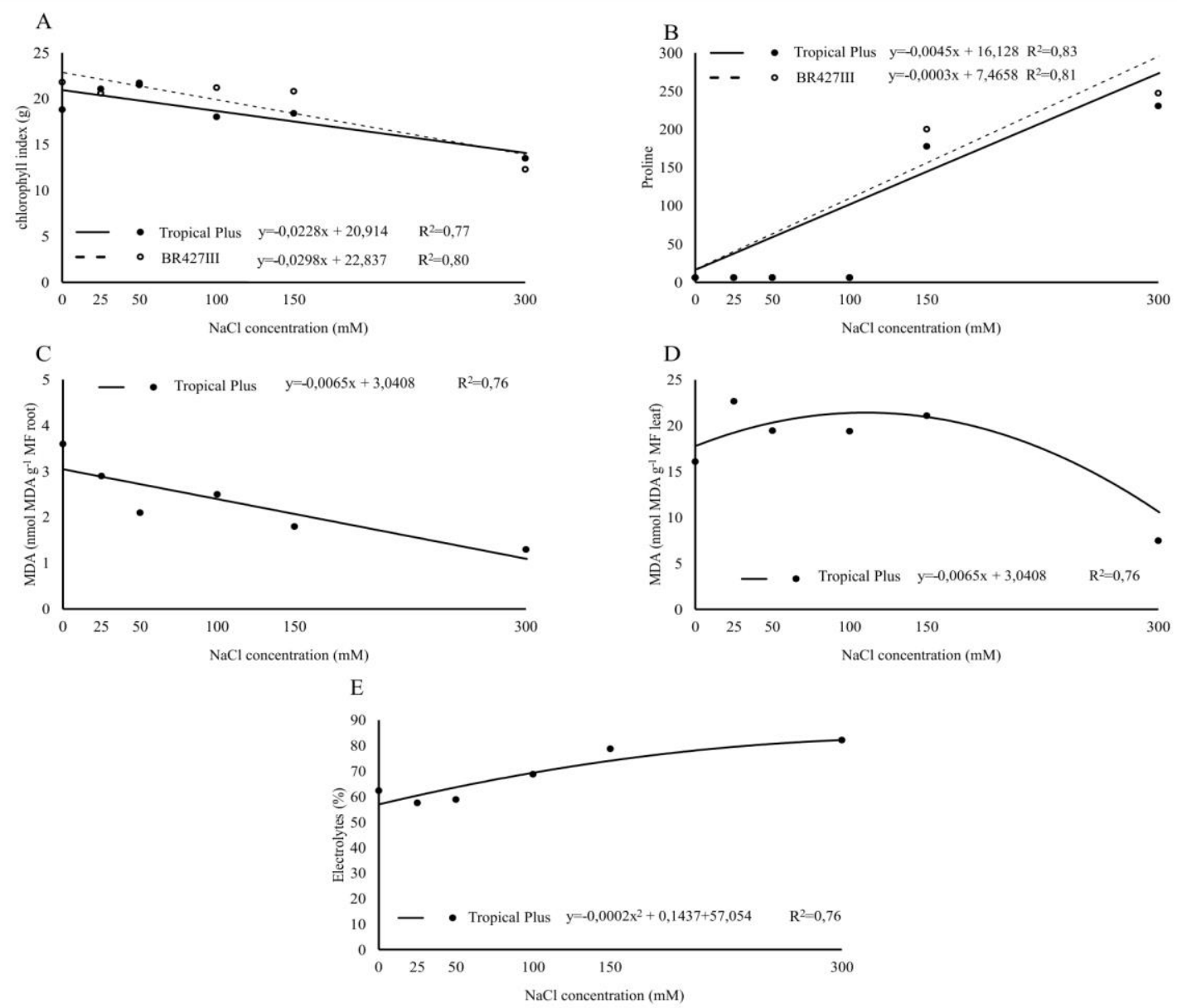

Figure 3. Chlorophyll index (Figure 3A), proline (Figure 3B), malonialdehyde (MDA) test in roots (Figure 3C) and leaves (Figure 3D), and electrolyte overflow (Figure 3E) in sweet corn genotypes, Tropical Plus and BR 427III, submitted to different saline concentrations $(\mathrm{NaCl})$ in the soil

The chlorophyll index (Figure 3A) decreased as $\mathrm{NaCl}$ concentration increased in the irrigation solution. The linear model adjusted better for both evaluated genotypes. This decrease may be related to the possible damage to the photosynthetic device, most specifically, the thylakoid membrane, interrupting the lipid bilayer or the lipid-protein complex, hindering the electron transport activity (Ambede et al., 2012).

This reduction can also be related to the sodium concentration increase in the tissue, and consequently in the chloroplast, affecting photosynthesis (Garcia et al., 2006), not only due to 
the stomatal closing but also the effect of salt on the activity of these structures (Daszkowska-Golec and Szarejko, 2013).

Proline occurs naturally in plants and normally accumulates in great concentrations in response to stress. According to some studies, this osmoprotectant may act as a non-enzymatic antioxidant agent, especially due to its capacity to protect and stabilize antioxidant enzymes such as superoxide dismutase (SOD), ascorbate peroxidase (APX) and catalase (CAT) (Rejeb et al., 2014).

The results made proline accumulation in both evaluated sweet corn genotypes evident (Figure 3B). An increment in proline concentration was observed in function of the salinity increase. However, this increase was greater for BR 427III genotype at $\mathrm{NaCl}$ concentrations of 150 and $300 \mathrm{mM}$, suggesting that it has a better response to saline stress. On the other hand, AbdElgawad et al. (2016) did not observe a significant difference between the assessed $\mathrm{NaCl}$ concentrations $(0,75$ and $150 \mathrm{mM})$ for the root and a decrease in the corn seedlings.

One of the techniques to evaluate lipid peroxidation is the malonialdehyde (MDA) test, because it is considered an oxidative stress biochemical marker (Shulaev \& Oliver, 2006). The concentration deployment of each genotype of regression was significant only for Tropical Plus roots (Figure 3C) as well as its leaves (Figure 3D). The genotypes differed statistically between themselves $(\mathrm{p} \leq 0.05)$ at all evaluated concentrations, except at $300 \mathrm{mM}$ (roots and leaves).

In both sweet corn genotypes, a reduction of malonialdehyde concentration in the root was observed while stress severity increased. In leaves, however, MDA accumulation was greater than in the root.

Malonaldehyde content decreased in BR 427III, but Tropical Plus presented an increase in this oxidative marker at 25, 50, 100 and $150 \mathrm{mM}$ of $\mathrm{NaCl}$, followed by a decrease at $300 \mathrm{mM}$.

The concentration increase in antioxidant molecules and proline presented low MDA content at the concentrations of 150 and $300 \mathrm{mM}$, especially in roots. The reduced MDA value suggests that the antioxidant defense mechanisms (proline and malonialdehyde) may have protected the membranes from the effects of oxygen-reactive species (ORS) provided by the oxidative stress.

The increase in $\mathrm{NaCl}$ concentration resulted in the increment of the membrane damage percentage, causing electrolyte overflow (Figure 3E). The concentration deployment of each genotype was significant only for Tropical Plus (Table 6). The genotypes differed statistically between themselves $(\mathrm{p} \leq 0.05)$ at the concentrations of 50 and $150 \mathrm{mM}$.

The genotypes presented significant increase in electrolyte deployment according to the salinity increase. Tropical Plus presented greater electrolyte overflow than BR 427III at 150 $\mathrm{mM}$ of $\mathrm{NaCl}$, but at the concentration of $50 \mathrm{mM}$ BR427 showed greater overflow than Tropical Plus (Figure 3E).

High salinity levels have been associated with the induction of oxidative stress in different plant tissues (Chawla et al., 2013). Under saline stress, ORS increases in vegetal tissues in response to irregularities of the electron transport chain and the accumulation of photo 
reduction strength. This electrochemical energy excess can be dissipated by Mehler's reaction, generating ORS, including $\mathrm{H}_{2} \mathrm{O}_{2}$ (Asada, 1999 and Chawla et al., 2013) which was not observed in this study.

This suggests that the plasmatic membranes were preserved despite the exposure to high concentrations of $\mathrm{NaCl}$. It is likely that the preservation of the membrane integrity represented by the low values of MDA (Figure 3C and 3D) and the electrolyte overflow (Figure 3E) are consequences of the non-enzymatic antioxidant defense mechanism action.

\section{Conclusion}

- BR427III presented increase in the concentration of protective metabolites such as proline.

- The activity of oxidative stress marker is lower in BR427III compared to Tropical Plus, therefore, minimizing lipid peroxidation and electrolyte overflow.

- BR427III is more tolerant to saline stress than Tropical Plus regarding the salinity conditions evaluated in this study.

\section{Acknowledgements}

The authors thank Paranaense University and Coordenação de Aperfeiçoamento de Pessoal de Nível Superior - CAPES for the financial support.

\section{References}

AbdElgawad, H., Zinta, G., Hegab, M. M., Pandey, R., Asard, H., \& Abuelsoud, W. (2016). High salinity induces different oxidative stress and antioxidant responses in maize seedlings organs. Frontiers in Plant Science, 7, 1-11. https://doi.org/10.3389/fpls.2016.00276

Acosta-Motos, J. R., Ortuño, M. F., Bernal-Vicente, A., Diaz-Vivancos, P., Sanchez-Blanco, M. J., \& Hernandez, J. A. (2017). Plant responses to salt stress: Adaptive mechanisms. Agronomy, 7, 1-38. https://doi.org/10.3390/agronomy7010018

Ahmed, I. M., Nadira, U. A., Bibi, N., Cao, F., He, X., Zhang, G., \& Wu, F. (2015). Secondary metabolism and antioxidants are involved in the tolerance to drought and salinity, separately and combined, in Tibetan wild barley. Environmental and Experimental Botany, 111, 1-12. https://doi.org/10.1016/j.envexpbot.2014.10.003

Ambede, J. G., Netondo, G. W., Mwai, G. N., \& Musyimi, D. M. (2012). NaCl salinity affects germination, growth, physiology, and biochemistry of bambara groundnut. Brazilian Journal of Plant Physiology, 24, 151-160. http://dx.doi.org/10.1590/S1677-04202012000300002

Asada, K. (1999). The water-water cycle in chloroplasts: Scavenging of active oxygens and dissipation of excess photons. Annual Review of Plant Biology, 50, 601-639. https://doi.org/10.1146/annurev.arplant.50.1.601

Bates, L. S., Waldren, R. P., \& Teare, I. D. (1973). Rapid determination of free proline for water-stress studies. Plant and Soil, 39, 205-207. https://doi.org/10.1007/BF00018060

Bezerra, A. K. P., Lacerdaii, C. F., Hernandez, F. F. F., Silvai, F. B., \& Gheyi, H. R. (2010) 
Rotação cultural feijão caupi/milho utilizando-se águas de salinidades diferentes. Ciência Rural, 40, 1075-1082. https://doi.org/10.1590/S0103-84782010000500012

Brito, M. E. B., Araújo Filho, G. D., Wanderley, J. A. C., Melo, A. S., Costa, F. B., \& Ferreira, M. G. P. (2013). Crescimento, fisiologia e produção do milho doce sob estresse hídrico. Bioscience Journal, 29, 1244-1254.

Cakmak, I., \& Horst, J. (1991). Effect of aluminium on lipid peroxidation, superoxide dismutase, catalase, and peroxidase activities in root tips of soybean (Glycine max). Physiologia Plantarum, 83, 463-468.

https://doi.org/10.1111/j.1399-3054.1991.tb00121.x

Carmo, C. D. S., Araujo, W. S., Bernardi, A. D. C., \& Saldanha, M. F. C. (2000). Métodos de analise de tecidos vegetais utilizados na Embrapa Solos. Rio de Janeiro: Embrapa Solos. p. 41.

Chawla, S., Jain, S., \& Jain, V. (2013). Salinity induced oxidative stress and antioxidant system in salt-tolerant and salt-sensitive cultivars of rice (Oryza sativa L.). Journal of Plant Biochemistry and Biotechnology, 22, 27-34. https://doi.org/10.1007/s13562-012-0107-4

Cruz, F. J. R., Junio, D. C. F., \& Santos, D. M. M. (2018). Low salt stress affects physiological parameters and sugarcane plant growth. Australian Journal of Crop Science, 12(8), 1272-1279. https://doi.org/10.21475/ajcs.18.12.08.PNE999

Daszkowska-Golec, A., \& Szarejko, I. (2013). Open or close the gate - Stomata action under the control of phytohormones in drought stress conditions. Front. Plant Sci., 4, 1-16. https://doi.org/10.3389/fpls.2013.00138

Farooq, M., Hussain, M., Wakeel, A., \& Siddique, K. H. M. (2015). Salt stress in maize: effects, resistance mechanisms, and management. A review. Agron. Sustain. Dev., 35, 461-481. https://doi.org/10.1007/s13593-015-0287-0

Ferreira, D. F. (2011). Sisvar: A computer statistical analysis system. Ciência e Agrotecnologia, 35, 1039-1042. https://doi.org/10.1590/S1413-70542011000600001

Garcia, G. O., Ferreira, P. A., Miranda, G. V., Neves, J. C. L., Moraes, W. B., \& Santos, D. B. (2007). Teores foliares dos macronutrientes catiônicos e suas relações com o sódio em plantas de milho sob estresse salino. Idesia. 25, 93-106.

https://doi.org/10.4067/S0718-34292007000300010

Gheyi, H. R., Dias, N. S., Lacerda, C. F., \& Filho, E, G. (2016). Manejo da salinidade na agricultura: Estudos básicos e aplicado. Fortaleza: INCTSal. p. 504.

Guzel, S., \& Terzi, R. (2013). Exogenous hydrogen peroxide increases dry matter production, mineral content and level of osmotic solutes in young maize leaves and alleviates deleterious effects of copper stress. Botanical Studies, 54, 1-10. https://doi.org/10.1186/1999-3110-54-26

Hajibagheri, M. A., Harvey, D. M. R., \& Flowers, T. J. (1987). Quantitative ion distribution within root cells of salt-sensitive and salt-tolerant maize varieties. New Phytologist. 105, 367-379. https://doi.org/10.1111/j.1469-8137.1987.tb00874.x 
Hajlaoui, H., Ayeb, N. E., Garrec, J. P., \& Denden, M. (2010). Differential effects of salt stress on osmotic adjustment and solutes allocation on the basis of root and leaf tissue senescence of two silage maize (Zea mays L.) varieties. Industrial Crops and Products, 31, 122-130. https://doi.org/10.1016/j.indcrop.2009.09.007

Munns, R., \& Gilliham, M. (2015). Salinity tolerance of crops-what is the cost? New Phytologist, 208, 668-673. https://doi.org/10.1111/nph.13519

Munns, R., \& Tester, M. (2008). Mechanism of salinity tolerance. Annual Review of Plant Biology, 59, 651-681. https://doi.org/10.1146/annurev.arplant.59.032607.092911

Rejeb, K. B., Abdelly, C., \& Savouré, A. (2014). How reactive oxygen species and proline face stress together. Plant Physiology and Biochemistry, 80, 278-284.

https://doi.org/10.1016/j.plaphy.2014.04.007

Saadat, S., \& Homaee, M. (2015). Modeling sorghum response to irrigation water salinity at early growth stage. Agricultural Water Management, 152, 119-12.

https://doi.org/10.1016/j.agwat.2015.01.008

Santos, A. D., Ferreira, B. P., Oliveira, G. F., Batista, O. R., \& Costa, B. A. (2012). Produção e parâmetros fisiológicos do amendoim em função do estresse salino. Idesia, 30, 69-74. https://doi.org/10.4067/S0718-34292012000200009

Shtereva, L. A., Vassilevska-Ivanova, R. D., \& Karceva, T. V. (2015). Effect of salt stress on some sweet corn (Zea mays L. var. saccharata) genotypes. Archives of Biological Sciences, 67, 993-1000. https://doi.org/10.2298/ABS150121062S

Shulaev, V., \& Oliver, D. J. (2006). Metabolic and proteomic markers for oxidative stress. New tools for reactive oxygen species research. Plant Physiology. 141, 367-372.

https://doi.org/10.1104/pp.106.077925

Silveira, J. A. G., Melo, A. R. B., Viégas, R. A., \& Oliveira, J. T. A. (2001). Salinity-induced effects on nitrogen assimilation related to growth in cowpea plants. Environmental and Experimental Botany. 46, 171-179. https://doi.org/10.1016/S0098-8472(01)00095-8

Wakeel, A. (2013). Potassium-sodium interactions in soil and plant under saline-sodic. Journal of Plant Nutrition and Soil Science. 176, 344-354. https://doi.org/10.1002/jpln.201200417

Willadino, L., Oliveira Filho, R. A., Silva Junior, E. A., Gouveia Neto, A. G., \& Camara, T. R. (2011). Estresse salino em duas variedades de cana-de-açúcar: enzimas do sistema antioxidativo e fluorescência da clorofila. Revista Ciência Agronômica, 42, 417-422.

https://doi.org/10.1590/S1806-66902011000200022

\section{Copyright Disclaimer}

Copyright for this article is retained by the author(s), with first publication rights granted to the journal.

This is an open-access article distributed under the terms and conditions of the Creative Commons Attribution license (http://creativecommons.org/licenses/by/4.0/). 